YEARBOOK
of ANTITRUST
and REGULATORY
STUDIES
www.yars.wz.uw.edu.pl

Peer-reviewed scientific periodical, focusing on legal and economic issues of antitrust and regulation. Creative Commons Attribution-No Derivative Works 3.0 Poland License.

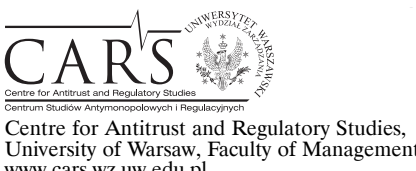

www.cars.wz.uw.edu.pl

\title{
Is the parallel competence set out in Regulation 1/2003 totally clear? Case comment to the preliminary ruling of the Court of Justice of 3 May 2011 Tele 2 v Prezes Urzędu Ochrony Konkurencji i Konsumentów (Case C-375/09)
}

\section{Background of the case - from the UOKiK President's decision to the Supreme Court}

With a motion dated $28^{\text {th }}$ of April 2005 submitted to the President of the Office of Competition and Consumer Protection (in Polish: Prezes Urzędu Ochrony Konkurencji i Konsumentów; hereafter, UOKiK President), Tele2 Polska Sp. z o.o. (currently: Netia S.A., hereafter, Applicant) requested the initiation of antitrust proceedings against Telekomunikacja Polska S.A. (hereafter, TP). The Polish incumbent, TP, was alleged to have engaged in practices restricting competition covered by Article 8(1) and 8(2)(5) of the Act on Competition and Consumer Protection of $15^{\text {th }}$ December 2000 (hereafter, Competition Act 2000) and in Article 82 of the Treaty establishing European Community (hereafter, TEC), presently, Article 102 of the Treaty on the functioning of the European Union (hereafter, TFEU).

The Applicant pointed out that TP's actions, in the form of offering to its clients the cheapest service package available among initial offers - the so called 'social package' - in exchange for their obligation to use only TP services (the Applicant changed the wording later on into: 'the use of exclusivity clause for the usage of publicly available telephone services'), should be considered as practices which restrict competition. In the assessment of the Applicant, such clauses violated antitrust rules because the subscribers of the cheapest package could not use the services of other operators, which offered telephone number selection (further on modified by the Applicant to 'access number') and pre-selection services.

After concluding antitrust proceedings, the UOKiK President issued on $28^{\text {th }}$ June 2006 a decison (DOK - 112/06) which analyzed if a breach occurred of Polish antitrust rules as well as of Article 82 TEC (now Article 102 TFEU).

In relation to Polish legislation, Article 11(1) in connection with Article 8(1) and 8(2)(5) of the Competition Act 2000 were considered. The UOKiK President concluded that TP did not engage in restrictive practices in the form of preventing the formation of conditions necessary for the creation or development of competition 
through the application of an exclusivity clause for the use of its publicly available telephone services on the domestic market of access to telephone services in the public fixed telephone network, which are provided on the basis of access number and pre-selection services.

In terms of EU competition law (Point II of the decision), the UOKiK President discontinued the above proceeding on the basis of Article 105 of the Polish Administrative Procedure Code (hereafter, KPA) in connection with Article 80 of the Competition Act 2000 and Article 5 Regulation 1/2003 ${ }^{1}$ and Article 82 TEC (hereafter, Article 102 TFEU). In Point III, the UOKiK President decided on the costs ${ }^{2}$.

The Applicant, Tele2 Polska Sp. z o.o., appealed this decision to the Polish Court of Competition and Consumer Protection (in Polish: Sad Ochrony Konkurencji $i$ Konsumentów; hereafter, SOKiK). In a judgment dated $29^{\text {th }}$ October 2007, SOKiK repealed Points II and III of the decision simultaneously rejecting the appeal as to its remainder and ruled on the costs ${ }^{3}$. In SOKiK's opinion, as long as there is no basis for concluding that the conditions for prohibition are met, the UOKiK President is entitled to issue a 'no grounds for action' decision. SOKiK established therefore a breach of Article 105 KPA in connection with Article 80 of the Competition Act 2000 because the proceedings were not unsubstantiated within the meaning of Article 105 KPA. The subject of the proceeding was to assess whether the contested practice of TP constituted an abuse of its dominant position or not. According to SOKiK, the authority could issue a decision on the merits (instead of discontinuing the proceeding $)^{4}$.

The Defendant, in this case the UOKiK President, lodged an appeal to the Court of Appeals in Warsaw ${ }^{5}$. On $10^{\text {th }}$ of July 2008, the second instance court ruled to dismiss the appeal. The Court of Appeals justified its ruling by pointing out that the substantive part of the decision of the UOKiK President was legally decided. It was, therefore, valid to assent that TP did not, in fact, engage in a practice limiting competition which was the subject of the proceeding. According to the Court of Appeals' assessment, if the UOKiK President settled the substantive matter of the original dispute - the legal compliance of TP's actions - then SOKiK accurately recognized that there was no basis for the enlargement of the matter of the dispute by the defendant by referring to Article 5 Regulation1/2003, if this did not influence either the essence of the dispute or the essence of the final decision.

The UOKiK President submitted a cassation appeal to the ruling of the second instance court. The UOKiK President alleged a violation of: Article 3(1) Regulation

1 Council Regulation (EC) No 1/2003 of 16 December 2002 on the implementation of the rules on competition laid down in Articles 81 and 82 of the Treaty $O J L$ 1, 4.1.2003.

${ }^{2}$ Decision of the UOKiK President of 28 September 2006, DOK-112/06 (available at www. uokik.gov.pl).

3 Judgment of the Court of Competition and Consumer Protection of 29 October 2007 (Ref. No. XVII AmA 122/06).

${ }^{4}$ From the justification of above mentioned judgment.

5 Judgment of the Court of Appeals in Warsaw of 10 July 2008 (Ref. No. VI ACa 8/08). 
1/2003 through its non-compliance, Article 5 Regulation 1/2003 through its misapplication and, Article 105 KPA through its misinterpretation and improper use.

As the Supreme Court stated, the essence of the problem to be solved lied in whether the national competition authority (hereafter, NCA) was entitled to - in accordance with the principle of procedural autonomy - issue a decision that the investigated practice did not constitute a forbidden practice under Article 102 TFEU (so called 'negative decisions') ${ }^{6}$, or whether the NCA is entitled only to issue a 'no grounds for action' decision using directly Article 5(3) Regulation 1/20037.

The Supreme Court stressed in the reasoning of its judgment that there are no doubts that a decision regarding the lack of a competition law violation, issued on the basis of Article 11 of the Competition Act, is not mentioned in the catalogue of decisions listed in Article 5(2) Regulation 1/2003. What raises doubts, however, is the question whether the NCA is entitled to - taking into account the wording of Article 5(3) Regulation 1/2003 - issue such a decision on the basis of domestic legislation in the light of Article 102 TFEU $^{8}$.

The Polish Supreme Court acknowledged that the wording of Article 5 Regulation 1/2003 raises interpretation doubts and constitutes the subject of divergent doctrinal interpretations where it concerns 'deciding about no grounds for action' from an NCA if it is found that a dominant company did not, in fact, abuse its position. Moreover, since the interpretation of Regulation 1/2003 was necessary for the Supreme Court to assess the legality of the contested judgment and the Court of Justice of the European Union (hereafter, CoJ EU) did not yet provide an interpretation of Article 5 Regulation 1/2003; the Polish Supreme Court concluded that it was necessary to seek an interpretation of the said rule directly from the CoJ EU'.

The Supreme Court submitted two questions to the CoJ EU:

1. Does Article 5 Regulation $1 / 2003$ need to be interpreted so that an NCA is precluded from issuing a decision declaring constitutively that a given practice does not restrict competition within the meaning of Article 102 TFEU if the NCA establishes, after conducting its proceedings, that a dominant company has not infringed the prohibition of Article 102 TFEU?

2. If the answer to the first question is in affirmative, does Article 5(3) Regulation $1 / 2003$ need to be interpreted so as to constitutes a direct legal basis for an NCA to issue a 'no grounds for action decision' if domestic legislation provides only for the possibility to close such proceeding (where no violation of Article 102 TFEU is found) by way of issuing a decision declaring that the scrutinized practice does not restrict competition?

${ }^{6}$ For the purposes of this text, a "negative" decision means a decision taken on the merits where a competition authority stated that there has been no breach of Article 101 or Article 102 TFEU.

7 Resolution of the Supreme Court of 15 July 2009 (Ref. No. III SK 2/09). See: point 3 of this decision.

8 Ibidem, point 10 .

9 Ibidem, point 19. 


\section{Preliminary ruling of the Court of Justice}

In the judgment C-375/09 dated $3^{\text {rd }}$ May 2011, the Grand Chamber of the Court of Justice (hereafter, CoJ) answered the two questions formulated by the Polish Supreme Court in the case concerning a cassation appeal lodged by the UOKiK President ${ }^{10}$. The formulation of the judgment was preceded by the opinion of Advocate General Ján Mazák presented on $7^{\text {th }}$ December $2010^{11}$.

Referring to the first question, the CoJ pointed out that in accordance with Article 3(1) Regulation 1/2003, where NCAs apply competition law to abusive behaviour of a dominant company that may harm EU trading conditions, they are to apply both Article 102 TFEU as well as appriopariate national laws ${ }^{12}$. Article 5(1) Regulation 1/2003 describes the powers assigned to NCAs when applying Article 101 and 102 TFEU to individual cases. Accordingly, NCAs can issue substantive decisions of the following kind: decisions requiring that the infringement be brought to an end; ordering interim measures; accepting commitments; imposing fines, periodic penalty payments or any other penalty provided for in their national law ${ }^{13}$. Article 5(2) Regulation 1/2003 additionally provides that if an NCA comes, on the basis of available information, to the conclusion that the conditions of establishing a violation of Article 101 or 102 TFEU were not met, they can decide that there are no grounds for action on their part ${ }^{14}$. As the CoJ stated, Article 5(2) Regulation 1/2003 explicitly points out that in such cases, NCAs are only entitled to issue a decision of the 'no grounds for action' type.

In the opinion of the CoJ, interpreting the powers vested in NCAs in this way is also supported by the granting to the Commission of the right to issue decisions in cases where no infringements of Article 101 and 102 TFEU are found, which explicite enacts Article 10 Regulation $1 / 2003^{15}$. According to the latter rule, if EU's public

10 Judgment of the Court (Grand Chamber) of 3 May 2011 in case C-375/09, reference for a preliminary ruling under Article 234 EC from the Sąd Najwyższy (Poland), made by decision of 15 July 2009, received by the Court on 23 September 2009, in the proceedings Prezes Urzedu Ochrony Konkurencji i Konsumentów v Tele2 Polska sp. z o.o., now Netia SA.

11 Opinion of Advocate General Mazák delivered on 7 December 2010 in case C-375/09, Prezes Urzędu Ochrony Konkurencji i Konsumentów v Tele2 Polska sp. zoo, now Netia SA $w$ Warszawie.

12 See para. 20 of the judgment.

13 Ibidem, para. 21.

14 Ibidem, para. 22.

15 As the Court noted, Recital 14 of the Regulation states that issuing by the Commission of such declarative decisions may occur in exceptional cases. According to this motive, issuing of such decisions is motivated the wish to make EU "law clearer while ensuring its uniform application in EU, particularly in relation to new types of agreements and practices, which were not mentioned in existing legislation and administrative practice." The Advocate General highlighted also that if the main goal of the EU legislator was to facilitate a situation where NCAs may issue decisions stating that a certain practice does not limit competition (as provided by the Polish Competition Act), the EU legislator would include such decisions in the list of Article 5 Regulation 1/2003 (or at least, in any other part of this Regulation, as is the case with decision described in Article 29(2)), vide: point 27 of the opinion. 
interest relating to the application of Article 101 and 102 TFEU so requires, the Commission, acting on its own initiative, may by decision find that Article 101 TFEU is not applicable to an agreement, a decision by an association of undertakings or a concerted practice either because the conditions of Article 101(1) TFEU are not fulfilled, or because the conditions of Article 101(3) are satisfied. The Commission may likewise make such a finding with reference to Article 102 TFEU $^{16}$. It follows from the above that EU legislature conferred thereby on the Commission the exclusive competence to adopt "negative" decisions on the merits, that is, decisions on the inapplicability of the prohibitions contained in Article 101 and 102 TFEU 17.

The Court noted also the cooperation mechanism between the European Commission and NCAs, established under the framework of the general principle of loyal cooperation and ensuring consistent application of competition principles in the Member States. Thus, if NCAs were to be granted with the right to issue 'no violation of Article 102 TFEU' decisions, that, in itself, would undermine the mechanism of cooperation and harm the powers granted to the Commission. 'Negative' substantive decision could, in the CoJ's opinion, hinder the achievement of the goal of ensuring a uniform application of Article 101 and 102 TFEU because the possibility of issuing such decisions may constitute an obstacle for a subsequent finding by the Commission that a given practice violates TFEU provisions after all ${ }^{18}$.

The CoJ stated, therefore, that it derives from both the wording and the structure of Regulation 1/2003 that the issuance of 'non-violation of Article 102 TFEU' decisions lies in the exclusive competence of the European Commission. That is so even in cases when Article 102 TFEU is applied during proceeding conducted by a NCA ${ }^{19}$.

Ipso facto, the CoJ answered the first of the Supreme Court's questions by stating that Article 5 Regulation 1/2003 should be interpreted to exclude the possibility of issuing by a NCA of a 'non-violation of Article 102 TFEU' decision in cases when in order to apply that provision, an NCA investigates whether the conditions for the application of Article 102 TFEU were fulfilled and subsequently arrives at the conclusion that an existing dominant position was not abused ${ }^{20}$.

Referring to the second question, the CoJ concluded that taking into account the answer provided to the first question, an NCA is not entitled to issue a decision on 'non-violation of Article 102 TFEU'21. According to Article 5(2) Regulation 1/2003, an

16 Point 34 of the Advocate General's opinion.

17 Ibidem, point 35.

18 The Advocate General referred here to the Otto case (ECJ judgment of 10/11/93, No $\mathrm{C}-60 / 92$ ) where it was concluded that "in principle, national authorities adapt Article 101 and 102 of TFEU in accordance with national procedural regulations. Subject to compliance with regulations [EU], in particular with its basic principles, to domestic legislation belongs defining procedural regulations suitable to guarantee interested entities the right to defend. Such guarantees may vary from those which apply in [EU] proceedings'. Point 20 of the opinion.

19 Para. 29 of the judgment.

20 Ibidem, para. 30.

21 The Advocate General pointed out that Article 5 Regulation 1/2003 is directly applicable and that a NCA may close its proceedings with a procedural decision finding that there are 
NCA may however - after concluding that the premises for establishing that a practice violated the prohibition of Article 102 TFEU were not fulfilled - issue a decision on the 'no grounds for action' by that $\mathrm{NCA}^{22}$. The CoJ recalled that an NCA may apply national legislation only when EU law does not provide any special rules on the issue at stake. However, due to the fact that Article 5 Regulation 1/2003 is directly applicable in the entire EU, domestic laws, which require the NCA to close antitrust proceedings conducted on the basis of EU law by way of a decision establishing the lack of an Article 102 infringement, are inconsistent with Article 5 Regulation 1/200323.

\section{Case comment}

According to Recital 6 Regulation 1/2003, in order to ensure effective application of EU competition rules, NCAs should be associated more closely with their enforcement. To this end, they should be empowered to apply EU law ${ }^{24}$. Ensuring the uniform application of EU competition law constitutes one of the key goals of Regulation 1/2003, perceived as a milestone in the modernization process of EU competition law and most of all, in the enforcement of competition rules.

In order to achieve this, Regulation 1/2003 creates a system of parallel competences whereby NCAs can apply Articles 101 and 102 TFEU in their entirety alongside the European Commission (Article 5 Regulation 1/2003). Decentralized enforcement is further encouraged by the possibility of information exchange (Article 12) and the possibility of assistance between NCAs in their investigations (Article 22) ${ }^{25}$. The current enforcement system inherently involves a process of an increased Europeanization/ convergence of the competition law regimes of all EU Member States ${ }^{26}$.

Importantly in this context, the duty to apply EU law does not prohibit or exclude the parallel application of national laws. Although this very point was hotly contested during the negotiations over the modernization proposal, the final version of Regulation 1/2003 does not preclude NCAs from applying domestic competition

no grounds for action on its part. First, like all EU regulations, Regulation 1/2003 is directly applicable in all Member States. Second, the principle of primacy requires the referring court to refrain from applying national laws contrary to EU legislation and to apply EU law instead. A national court which is called upon, within the limits of its jurisdiction, to apply EU law is under an obligation to apply the latter refusing, if necessary, to apply any conflicting national provisions, even if the latter was adopted after EU law. It is not necessary for the court to request or await the prior setting aside of such domestic provisions by legislative or other constitutional means. See points 56 and 59 of the opinion.

22 Para. 32 of the judgment.

23 Ibidem, para. 33-34.

24 Recital 6 of Regulation 1/2003.

25 Commission Notice on the handling of complaints by the Commission under Articles 81 and 82 of the EC Treaty [OJ] 2004 C 101/5, point 19.

${ }^{26}$ K. J. Cseres, 'The Impact of Regulation 1/2003 in the New Member States' (2010) 6(2) Competition Law Review 165. 
rules to cases assessed under EU law also, provided that the national law allows such parallel application ${ }^{27}$.

However, NCAs are not allowed to rule on an agreement, decision or concerted practice in a way contrary to a decision concerning the same practice issued earlier by the Commission. In cases when multilateral practices might have an influence on trade between EU Member States - NCAs are obliged to apply EU competition law. Such interpretation constitutes an emanation of the supremacy principle of EU competition law over the competition rules of its individual Member States ${ }^{28}$.

Clearly among the key issues stressed in the commented judgment is the possibility of a double ruling in the same court case - the ne bis in idem principle. In such cases, the inability to re-initiate certain proceedings should be perceived as a natural consequence of a decision issued by NCA that does not establish any kind of infringement.

As mentioned in literature, the multiplicity of increasingly active enforcers in the EU (the Commission and twenty-seven NCAs) poses the risk that firms will face cases of double jeopardy where several enforcers are seeking to prosecute and sanction the very same market conduct. In this light, there is a fundamental need for clarity as to the limits that the principle of ne bis in idem places on parallel actions by multiple enforcers. However, EU jurisprudence is yet to reflect the changes brought about by Regulation 1/200329. Going further, the wording of Regulation 1/2003 gives NCAs' the right to only issue substantive decisions that affirm a violation ('positive' decisions) but not decisions that would state that an infringement did not occur ('negative' decisions).

It should be pointed out that a different interpretation of this issue could result in the doubling of competences between the Commission and NCAs. As a result, a double violation of the ne bis in idem principle could take place. First of all, as stressed by Advocate General Mazak ${ }^{30}$, 'negative' decision issued by NCAs' could prevent the Commission from a subsequent finding of a violation of Article 101 or 102 TFEU. Second, issuing a 'negative' decision at the level of national legislation could preclude other NCAs' from deciding on a violation of EU competition rules.

Although Article 5 Regulation 1/2003 gave NCAs the right to apply Article 101 and 102 TFEU directly ${ }^{31}$, it did not empower them to take 'negative' decisions (inapplicability

27 D. J. Gerber, P. Cassinis, 'The 'Modernisation' of European Community Competition Law: Achieving Consistency in Enforcement - Part I' (2006) 27(10) E.C.L.R. 12.

28 NCAs are entitled to the parallel use of EU and national law. However, the scope of application of the latter was gradually limited with the provisions of the Regulation 1/2003 A. Cieślińki, T. Korbutowicz, [in:] A. Cieśliński (ed.), Wspólnotowe prawo gospodarcze [EC economic law], vol. II, Warszawa 2007, p. 655-656.

${ }^{29}$ F. Louis, G. Accardo, 'Ne Bis in Idem, Part 'Bis' (2011) 34(2) World Competition 98. Authors add therein that case-law is still anchored in the system of 'shared competences' between the Commission and NCAs under the principles established in Walt Wilhelm case almost four decades ago.

30 See point 30 of the opinion.

31 In the Communication from the Commission to the European Parliament and the Council Report on the functioning of Regulation 1/2003 it is said, inter alia, that: 'Article 3(1) obliges 
of the prohibition) in the context of Articles 101 and 102 TFEU. Indeed, it is of little consequence that national procedural rules allow for such negative decisions with regard to the prohibitions under domestic competition laws. The principle of procedural autonomy does not legitimize an extension of the powers that NCAs can adopt under Regulation 1/2003 regarding decision types ${ }^{32}$.

Crucially, Article 5 is a very rudimentary rule. Regulation 1/2003 does not formally regulate or harmonize the procedures to be applied by NCAs aside from the content of its Article 5 and the rules it contains on cooperation. As a result, NCAs apply the same substantive rules (Article 101 and 102 TFEU) but according to divergent procedures (various national legislation) and may thus impose a variety of sanctions. In important respects, the Regulation reconciled the requirements of substantive coherence with the existing procedural diversity characterizing Member States' competition regimes ${ }^{33}$.

Unlike the more detailed provisions of Regulation 1/2003 concerning the decisionmaking powers of the Commission, Article 5 leaves a number of important questions unanswered. For instance, can NCAs impose behavioral as well as structural remedies? What is the maximum amount of fines and periodic penalty payments that they can impose $^{34}$ ?

Article 5 lists the powers of NCAs when applying Article 101 and 102 TFEU. These powers are expressed by a list of decisions that NCAs are entitled to take which includes: establishing an infringement; ordering interim measures; accepting commitments and; imposing fines. As it was highlighted in the Commission Staff Working Paper, the interpretation of Article 5 has given rise to certain queries during the period covered by the Report on the Functioning of Regulation 1/2003 to which it was attached. First, the question has arisen whether Article 5 is capable of direct effect, that is, if the powers listed in that provision are immediately and directly available to all NCAs even if not expressly provided for by national legislation. Absent of any jurisprudential guidance, this question is still subject to discussion. Its practical relevance has declined however insofar as NCAs gradually obtained additional powers pursuant to national laws. Second, the question has come up whether NCAs may adopt declaratory decisions in relation to past infringements. Given that Article 5 does not contain a provision equivalent to the last paragraph of Article 7(1) Regulation $1 / 2003$, doubts remains about whether the lack of an express provision may prevent

national competition authorities and courts to apply Articles $81 \mathrm{EC}$ and $82 \mathrm{EC}$ to agreements or conduct capable of affecting trade between Member States. This rule is intended to ensure that the EC competition rules are applied to all cases within their scope'. See point 20.

32 Pt. 50 of the opinion of Advocate General Mazák.

${ }^{33}$ Commission Staff Working Paper Accompanying The Communication From The Commission To The European Parliament And Council Report On The Functioning Of Regulation 1/2003, Brussels, 29.4.2009, SEC(2009) 574 final, points 200 - 201(available at: http://eur-lex.europa.eu).

34 W.P.J. Wils, 'EU Antitrust Enforcement Powers and Procedural Rights and Guarantees: The Interplay between EU Law, the Charter of Fundamental Rights of the EU and the European Convention of Human Rights' (2011) 34(2) World Competition 195. 
NCAs from taking a decision on the basis of Articles 101 and 102 TFEU in relation to past infringements in cases where they do not intend to impose a fine ${ }^{35}$.

Empowering NCAs to issue decisions confirming that no violation of Article 102 TFEU ("negative" decision) is taking or took place would undermine the mechanism of cooperation set out in the Regulation. In addition, it would stand in opposition to the rights granted by this very act to the Commission ${ }^{36}$. This in turn would undermine the primary aim of the Regulation, which is ensuring uniform (consistent) application of EU competition law ${ }^{37}$.

What is worth noting is the fact that the commented judgment highlighted also another important issue concerning the relations between the Commission and NCAs or, to be more precise, between EU law and national legislation, namely the principle of procedural autonomy. The Advocate General noted that Article 5 Regulation $1 / 2003$ limits procedural autonomy through the enumeration of the types of decisions that NCAs can issue in EU competition law cases. It should be emphasized here that it is the procedural provisions that constitute the scope of NCAs' independence (included in the European Competition Network) in the field of EU law enforcement. Ipso facto, the lack of the possibility to issue 'negative' decision should be perceived as an example of an 'attenuation' of the procedural autonomy of Member States.

As indicated by doctrine, the catalogue of decision types that NCAs can take in connection with Article 101 and 102 TFEU has a closed character. As a result, NCAs are not entitled to issue in this context any other kind of decisions than those listed in the Regulation, even if national legislation requires them to do $\mathrm{so}^{38}$. Speaking in favor of such interpretation, in the opinion of the Advocate General as well as doctrine, is the layout of the Regulation as such.

35 Commission Staff Working Paper..., point 197.

36 Opinion of the Advocate General, point 27.

37 Regulation 1/2003 stated that: "[I]n order to establish a system which ensures that competition in the common market is not distorted, Articles 101 and 102 of TFEU must be applied effectively and uniformly in the [EU]. The most specific procedural tool for promoting enforcement consistency is provided by Article 10 Regulation 1/2003. On its basis, the Commission can decide on its own to commence proceedings and to adopt decisions in light of EU's 'public interest'". A short explanation of this solution can be found in Recital 14 Regulation 1/2003: 'In exceptional cases where the public interest of the [EU] so requires, it may also be expedient for the Commission to adopt a decision of a declaratory nature finding that the prohibition in Article 101 and 102 of TFEU does not apply, with a view to clarifying the law and ensuring its consistent application throughout the [EU], in particular with regard to new types of agreements or practices that have not been settled in the existing case-law and administrative practice'.

38 C. Banasiński, M. Bychowska, 'Kompetencje decyzyjne Komisji Europejskiej i Prezesa UOKiK wynikające z rozporządzenia Rady UE 1/2003 w świetle zasady równoległego stosowania wspólnotowego i krajowego prawa antymonopolowego' ['Decisional powers of the European Commission and UOKiK President resulting from the Regulation 1/2003 from the perspective of a principle of parallel application of Community and national antitrust law'] (2003) 3 Przeglad Prawa Handlowego 6. 
Accordingly, if the EU legislator was going to give NCAs the power to issue 'negative' substantive decision regarding practices limiting competition (that is, lack of such practices) - this type of decision would be part of the catalogue listed in Article 5(1) Regulation 1/2003. A contrario, the absence of such provision suggests that NCAs cannot take decisions which establish the inapplicability of the EU prohibitions to a given practice.

It is worth noting that NCAs and national courts which apply EU law are associated with the assumptions of a rational legislator, which combined with the principle of EU law supremacy, indicates also that Member States are bound by the principle of rationality of the EU legislator. This assumption is connected in the law enforcement practice, with the inability of a broad interpretation of the law in cases when legislation is clearly formulated and the literal interpretation of its rules is not causing any interpretational problems ${ }^{39}$.

The commented judgment of the CoJ clarified also the demarcation line between the decision-making powers of the Commission and those of NCAs, explicitly pointing out the numerous decision types, the issuance of which lies in the competence of NCAs while adopting Article 101 and 102 TFEU.

Undoubtedly, the system set out by Regulation 1/2003 recognizes the special role of the European Commission and its decisions. These decisions anchor the EU competition law enforcement system by providing a basic source of stability in interpreting EU competition rules ${ }^{40}$.

In this decentralized system, the Commission, acting as the guardian of the Treaties and as an institution enjoying a central position in the network, has a special role to play in the determination of EU competition policy and ensuring that Articles 101 and 102 TFEU are uniformly applied in the entire internal market ${ }^{41}$. It is for that reason that it was considered necessary to provide the Commission with the legal title to issue both - 'positive' and 'negative' decisions. This competence enables the Commission to act on all grounds in order to enforce competition rules. Therefore, there are no doubts that in a 'heliocentric' 42 system covering the Commission and all of the 27 EU NCAs, the Commission remains at its center. Perfect examples confirming this thesis are present in Regulation1/2003 itself. They include Article 11(6), which states that the initiation by the Commission of proceedings for the adoption of a decision under Chapter III shall relieve NCAs of their competence to apply Articles 101 and 102 TFEU $^{43}$.

Competition law has played a central role in the integration of the European market, and the need to adapt it to new circumstances is recognized as imperative. The system chosen to achieve these goals faces, however, a major risk that could

39 C. Banasiński, M. Bychowska, 'Kompetencje...', p. 9.

40 D. J. Gerber, P. Cassinis, 'The 'Modernisation'...', p. 14.

41 It is worth noting Article 4 Regulation 1/2003, which constitutes a kind of open formula for legal entitlements assigned to the Commission.

42 Also called in literature 'radial' system - author's footnote.

${ }^{43}$ See Article 11(6) of Regulation 1/2003. 
undermine the effectiveness of competition law throughout Europe. The devolution of authority to Member State institutions creates the potential for divergent application and interpretation of European law ${ }^{44}$.

Aside from delivering a clear indication of the interpretation of Article 5 Regulation $1 / 2003$, it is important to note that the commented judgment highlights also some other essential issues. First of all, the CoJ pointed out the parallel aspects of competition law's enforcement in Europe establishing a subtle, yet unambiguous, boundary between the decision-making competences of the Commission and NCAs. Secondly, the CoJ referred to procedural autonomy and the ne bis in idem principle and pointed out that giving NCAs the entitlement to take 'negative' decision would be an obvious limitation of the Commission's powers. In cases where a decisions was issued by a NCA, the Commission could as a result not conduct the proceedings in the same matter.

It should also be stated that the judgment undoubtedly highlighted the importance of the Commission in its central role in the system of parallel application of EU competition law.

\section{Ilona Szwedziak}

Legal adviser

44 D. J. Gerber, P. Cassinis, 'The 'Modernisation'...', p. 11. 